\title{
IMPROVED PROFITS AND WETLAND PADDY FARMING SCALE AS THE LEADING COMMODITY IN AGROECOLOGICAL ZONES
}

\author{
Joko Mulyono', Setia Hadi ${ }^{2}$, Khursatul Munibah ${ }^{2}$ \\ ${ }^{1}$ Institute Center For Agricultural Technology Assesement And Developmnet \\ Jl. Tentara Pelajar No. 10, Bogor, West Java \\ ${ }^{2}$ Faculty of Economics and Management, Pascasarjana IPB \\ Correspondence E-mail: jokomulyono21@gmail.com
}

Recieved: January 2016; Accepted: June 2016

\begin{abstract}
This study aims to analyze the farming feasibility, the increase in net profit and the scale of farming of wetland paddy as a leading commodity according to agro ecological zones (AEZ). The study was conducted at the location of the wetland paddy as a leading commodity and non leading commodity Bantul Regency in 2015. The feasibility of farming is analyzed using revenue and cost ratio $(\mathrm{R} / \mathrm{C})$, the increase in profits is analyzed by an increase in net profit (NKB) and the scale of farming is analyzed by determining the break even point of production (TIP) or break even point of price (TIH). The results showed that wetland paddy farming as a leading commodity according to agro ecological zones in Bantul is feasible and more optimal (R/C 2.17) than the non leading commodity (R/C 1.99). Wetland paddy farming as a leading commodity according to agro ecological zones can raise the net profit (NKB 1.13). Wetland paddy farming as a leading commodity according to agro ecological zones can be profitable if the production is at least $2,729 \mathrm{~kg} / \mathrm{ha}$ or the price is at least Rp. 1,643/kg.
\end{abstract}

Keywords: profit, wetland paddy farming, leading commodity, agro-ecological zone JEL Classification: D51, E23

\section{Introduction}

Wetland area in Bantul Regency was 15,471

ha $(30.52 \%)$, non wetland area was 14,125 ha $(27.9 \%)$ and non-agricultural area was 21,089 (41.6\%). The total area of Bantul Regency was 50,685 ha (BPS Bantul Regency, 2014). In Province of Yogyakarta, Bantul Regency was the second rank acreage for wetland area after Sleman (22,642 ha). Wetland paddy harvested field area in 2013 amounted to 32,621 ha with a productivity of 6.41 tonnes/ha and it's production reached 209,149 tonnes. Wetland paddy harvested field area tend to increase $3.44 \%$, the production tends to increase $2.88 \%$, but productivity tends to decline $0.63 \%$. The development of the harvested area, production and productivity of food crops sub-sector (2011-2013) are presented in Table 1.

In doing farming activities, farmers rarely paid attention to whether the commodity that cultivated was a commodity that has a comparative advantage, competitive advantages and in accordance with agro-ecological zones (AEZ), so the productivity was low. Commodities that have comparative advantages indicates the commodity is produced through the dominance of natural resource support, where other areas are not able to produce. Commodities that have a competitive advantages indicates the commodity is produced in a way that is efficient and effective, so have a good competitiveness of the aspects of quality, quantity, continuity and price. Rusastra, 


\section{Jurnal Ekonomi Pembangunan, 17 (1), Juni 2016, 15-27}

Rachman and Friyantno (2004) revealed that financial gain indicates competitive advantage of a commodity, while the economic benefits of a commodity indicates a comparative advantage in resource utilization. Leading commodity means a commodity that has a strategic position to be developed in a region are decided based on various considerations, both technically (soil and climate) social and economic as well as having comparative and competitive advantages (IAARD, 2003). According Setiyanto (2013), a leading commodity is a commodity that is in accordance with the local agro-ecological and competitive advantage, good market in the region itself, in other areas in the national scope, as well as in international markets.

Table 1. Harvested Area, Production and Productivity Food Crops Sub Sector by Type of Plants (2011-2013)

\begin{tabular}{|c|c|c|c|c|c|c|c|c|c|}
\hline \multirow{3}{*}{$\begin{array}{l}\text { Type of } \\
\text { crop }\end{array}$} & \multicolumn{9}{|c|}{ Year } \\
\hline & \multicolumn{3}{|c|}{2011} & \multicolumn{3}{|c|}{2012} & \multicolumn{3}{|c|}{2013} \\
\hline & 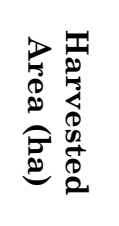 & 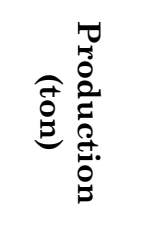 & 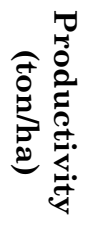 & 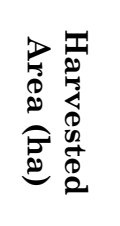 & 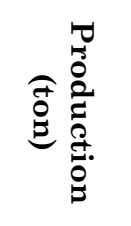 & 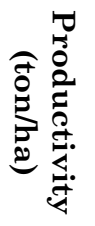 & 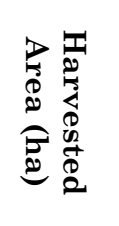 & 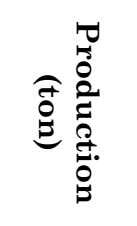 & 总 \\
\hline $\begin{array}{c}\text { Wetland } \\
\text { Paddy }\end{array}$ & 30,559 & 197,618 & 6.5 & 30,064 & 204,959 & 6.8 & 32,621 & 209,149 & 6.4 \\
\hline $\begin{array}{l}\text { Dryland } \\
\text { Paddy }\end{array}$ & 140 & 386 & 2.8 & 141 & 396 & 2.8 & 71 & 215 & 3.0 \\
\hline Maize & 3,892 & 23,081 & 5.9 & 4,244 & 23,304 & 5.5 & 3,371 & 19,077 & 5.7 \\
\hline Soybean & 3,074 & 4,355 & 1.4 & 2,415 & 3,987 & 1.7 & 1,412 & 2,203 & 1.6 \\
\hline Peanut & 3,205 & 3,470 & 1.1 & 3,226 & 4,082 & 1.3 & 2,451 & 3,335 & 1.4 \\
\hline Cassava & 2,307 & 44,033 & 19.1 & 2,237 & 35,236 & 15.8 & 1,925 & 34,865 & 18.1 \\
\hline Sweet potato & 18 & 182 & 10.1 & 25 & 248 & 9.9 & 64 & 649 & 10.1 \\
\hline
\end{tabular}

Source: BPS Bantul, 2014 (analyzed)

Agro ecological zones (AEZ) is a grouping of a region based on the physical environmental conditions which are almost the same, where the diversity of plants and animals is not differ significantly. The main component of agroecology is the climate (temperature and precipitation), physiographic region or shape (flat, wavy to mountainous) and soil (acidity, texture and drainage). Farming with commodities that not correspond to agro ecological zones (AEZ) can lead to low agricultural productivity, rising farming costs (production costs) and damage to the environment or ecosystem. According Syafruddin et al.(2004), a farming system that is efficient, high production and sustainable can be achieved among others by utilizing land resources based on characteristics, ability and suitability and supported by technology and appropriate government policies. Farming with a leading commodity according to agro ecological zones (AEZ) is one form of farming that aims to increase production, reduce costs thereby increasing profit. According Hendayana (2003), that in order to achieve the efficiency of agricultural development can be done by developing a commodity that has a comparative advantage both in terms of the supply and demand. From the supply side, leading commodities characterized by excess (superiority) in growth in biophysical conditions, technological and socio-economic farmer. On the demand side, the leading commodity market characterized by strong demand domestically and internationally. 


\section{Jurnal Ekonomi Pembangunan, 17 (1), Juni 2016, 15-27}

According Sukmayani et al. (2014), development of leading commodities are different for each area/region depending on the characteristics and potential local resources.

Wetland paddy is a leading commodity according to agro ecological zones (IV/Wrh) on food crops sub-sector in Bantul by Loqation Quotient (LQ) > 1, Shift Share Analysis (SSA) is positive and in accordance with the zoning of agricultural commodities (Mulyono, 2015). Wetland paddy as the leading commodity was spread out in 10 sub-districts, namely Sanden, Kretek, Pundong, Bambanglipuro, Pandak, Bantul, Jetis, Banguntapan, Kasihan and Sedayu with area $11,666.66$ ha (23\%). This study purposed to analyze the farming feasibility, the increase in net profit and the scale of farming of wetland paddy as a leading commodity according to agro ecological zones (AEZ).

\section{Research Method}

\subsection{Location and Time Research}

The study was conducted in 2015 at the sites of the wetland paddy fields as a leading commodity, namely: 1). Panjangrejo Village, Pundong District, 2). Srigading Village, Sanden District and 3). Tirtomulyo Village, Kretek District, Bantul Regency and wetland paddy fields as a nonleading commodity, namely: 1). Panggungharjo Village, Sewon District, 2). Sriharjo, Imogiri District and 3). Srimartani Village, Piyungan District, Bantul Regency. The criteria of wetland paddy as a leading commodity were (1) LQ > 1, (2) SSA positive and (3) appropriate with AEZ, vice versa if at least one criterion was unfulfilled.

\subsection{Types and Data Collection Methods}

The data used in this research are secondary and primary data. Secondary data were obtained from publications Bantul Central Bureau of Statistics, Department of Agriculture and Forestry Bantul and Assessment Institute for Agricultural Technology (AIAT) Yogyakarta and any relevant research results such as wetland paddy area, harvested area, production and productivity. The primary data were obtained through interviews with respondents/farmers using a structured questionnaire. The questionnaire is intended to provide guidance to the enumerators questions in the interview, so focus and be able to answer the research objectives. Respondents were selected by stratified random sampling approach. The number of respondents are 30 farmers consisting of 15 farmers of wetland paddy as a leading commodity according to agro ecological zones (AEZ) and 15 farmers of wetland paddy as a nonleading commodity. The number of farmers from both of wetland paddy as a leading commodity and non-leading commodity were not identified properly. Juanda (2009) stated that if there is not any information of the variance of the population, sampling method can be applied at least for 30 samples, because according to the central limit theory estimated average would be closer to the normal distribution. Data collected includes: 1. Characteristics of respondents/farmer, 2. Tenure respondents/farmer, 3. Accessibility and infrastructure of research sites, 4 . The cost of production facilities cover the cost of seeds, fertilizers and pesticides or drugs, 5. Labor costs include the cost of land preparation, planting, fertilizing, spraying, harvesting and post-harvest, and 6. Production and price of grain.

\subsection{Data Analysis}

Feasibility of wetland paddy farming as a leading commodity according to agro ecological zones (AEZ) were analyzed using revenue and cost ratio $(\mathrm{R} / \mathrm{C})$, with $\mathrm{R} / \mathrm{C}>1$ for feasible. According to Soekartawi (2002), formulation for $\mathrm{R} / \mathrm{C}$ is presented as follows:

$\mathrm{R} / \mathrm{C}=\mathrm{TR} / \mathrm{TC}$

where TR is for total revenue and TC is for total cost.

To analyze the increase in net profit of wetland paddy farming as a leading commodity according to agro ecological zones (AEZ) used ratio of the increase in net profit (NKB). According 


\section{Jurnal Ekonomi Pembangunan, 17 (1), Juni 2016, 15-27}

Adnyana and Kariyasa (1995), the increase in net profit formulation is presented as follows:

$\mathrm{NKB}=\frac{\mathrm{KBs}}{\mathrm{KBts}}$

where NKB is the value of net profit, KBs is a net gain as a leading commodity wetland paddy farming according to agro ecological zones (AEZ) and KBts is a net gain as a non-leading commodity paddy farming.

Scale farming can be determined using a break even approach (Sudjana, 2007). Scale farming can be determined by the break even point of production (TIP) and the break even point of price (TIH). The break even point is determined at the time of $\mathrm{TR}=\mathrm{TC}$ or total revenue equal to the total cost of farming. According Rahmanto and Adnyana (1997), the break even point of production (TIP) and the break even point of price (TIH) formulated as follows:

$\mathrm{TIP}=\mathrm{BP} / \mathrm{H}$

$\mathrm{TIH}=\mathrm{BP} / \mathrm{P}$

where $\mathrm{P}$ is production $(\mathrm{kg}), \mathrm{H}$ is production price $(\mathrm{Rp} / \mathrm{kg})$ and $\mathrm{BP}$ is cost of production $(\mathrm{Rp})$.

\section{Results And Discussion}

\subsection{Farmers' Characteristics}

Characteristics of the farmers include age, education, farming experience, number of dependents, the main job and main income as shown in Appendix 1.

Farmers majority, were aged over 35 years (Table 2), this showed that the farmers are in the productive age. On the other hand, people in productive age were potentially in doing farming. The farmers had low level of formal education where as $46.66 \%$ to $93.33 \%$ of the farmers got education below the junior high school and $6.67 \%$ to $20 \%$ of them had senior high school level. The level of education affects the ability of farmers to receive and find information about new technologies that support farming activities. Suharyanto, Destialisma, and Parawati (2005), higher education encourages farmers to be more rational in managing farming. Isgin et al. (2008), the farmers decisions whether "to adopt" or "not to adopt" an innovation were extremely affected by the level of formal education. The farmers which got experiences in farming more than 26 years were $40 \%-60 \%$ and no one of the farmers got experiences less than 5 years. Experience in farming became a value in doing farming, such as the timing of planting, pest and diseases, etc. Experience in farming can be a driving force for introducing new technologies and to improve abilities to take rational decisions. Rangkuti (2009), the experience build the farmer character into more open and able to cooperate with other farmers in a network. The number of covered family members between 3-4 people for each (53.33\%), while $33.33 \%$ to $40 \%$ are between $1-2$ people for each. While number of covered family members which more than 5 people were $6.67 \%$ to $13.34 \%$. The main job of the farmers were $80 \%-100 \%$ as a farmer, and the rest were nonagricultural labors and others (village officials). The main income of respondents were $73.33 \%$ to $100 \%$ from farm production and more than $20 \%$ were from non-agricultural labors and $6.67 \%$ from village officials.

\subsection{Land Tenure of Farmers}

Land is known as a major asset for farm households related to farming activities. Land tenure became one of the indicators that used in the assessment for the level of welfare. The land tenure performance includs the type of land, land area and land ownership. Land types consist of irrigated land, rainfed areas, dry land and yard. The status of land tenure describes in three ways: its own, rent and profit sharing. The performance of land tenure is presented in Table 2.

The total area of land tenure by farmers were 0.32 to 0.53 ha for each, where the land tenure was dominated by irrigated land with an area 0.27 to 0.39 ha for each (Table 2). Land tenure status not only from its own farmers, but 


\section{Jurnal Ekonomi Pembangunan, 17 (1), Juni 2016, 15-27}

also were obtained through a system of rent or profit sharing. Land that was leased or shared was land owned by individuals and belong to the village. The price for paddy field rent reached 15 million/year/hectare. In a profit-sharing system, the percentage of revenue sharing based on the commodities that grown on fields. For the area planted with paddy, the distribution of the results are $50 \%$ for owners and $50 \%$ for tenants, with the provisions all of the production cost and labor from tenants. Land planted with crops, the distribution of the results were 1/3 (33.3\%) for owners and $2 / 3$ (66.7\%) for tenants with the provisions of all costs from tenants. Koirala, Mishra, and Mohanty (2016), land was a key factor in the agriculture production and land tenure had a significant impact on the technical efficiency.

Table 2. Performance of Land Tenure

\begin{tabular}{ccccccccc}
\hline & \multicolumn{4}{c}{ Land area (ha) and Status } \\
\cline { 2 - 9 } Type of land & \multicolumn{4}{c}{$\begin{array}{c}\text { Leading Commodity } \\
\text { According to AEZ }\end{array}$} & \multicolumn{5}{c}{$\begin{array}{c}\text { Non-Leading } \\
\text { Commodity }\end{array}$} \\
\cline { 2 - 9 } & Own & Rent & $\begin{array}{c}\text { Profit } \\
\text { sharing }\end{array}$ & Total & Own & Rent & $\begin{array}{c}\text { Profit } \\
\text { sharing }\end{array}$ & Total \\
\hline Irigated land & 0.08 & 0.10 & 0.09 & 0.27 & 0.18 & 0.02 & 0.19 & 0.39 \\
Rainfed & - & - & - & - & - & - & - & - \\
Dry land & - & - & - & - & 0.01 & - & - & 0.01 \\
Yard & 0.05 & - & - & 0.05 & 0.13 & - & - & 0.13 \\
Total & 0.13 & 0.10 & 0.09 & 0.32 & 0.32 & 0.02 & 0.19 & 0.53 \\
\hline
\end{tabular}

Source: primary data (analyzed)

\subsection{Accessibility and Infrastructure Research Area}

Accessibility and infrastructure are factors that affect the success in farming. The performances of farmer accessibility are a distance of a farmer house to the farm/field, to the input market, to the output market and to resources of information. Input market is the store or shop that provides or sells agricultural inputs such as seeds, fertilizers, pharmaceuticals (pesticides), etc. Market output is the store or shop that accepts and purchase of agricultural products. Sources of the information is the Institute of Agricultural Extension in each district. The function and role of the Institute of Agricultural Extension (BPP) is a provider of information that needed by farmers, extension to farmers, farmers assistance and the development of farmers. The performance of accessibilities of the research location is shown in Table 3.
Table 3. Accessibility Research Area

\begin{tabular}{cccc}
\hline No & Brief & $\begin{array}{c}\text { Leading } \\
\text { Commodity } \\
\text { According } \\
\text { to AEZ } \\
\text { (km) }\end{array}$ & $\begin{array}{c}\text { Non-Leading } \\
\text { Commodity } \\
\text { (km) }\end{array}$ \\
\hline 1 & $\begin{array}{c}\text { Distance to } \\
\text { farm/field } \\
\text { Distance } \\
\text { to input } \\
\text { market }\end{array}$ & 0.63 & 0.67 \\
3 & 1.61 & 1.50 \\
3 & $\begin{array}{c}\text { Distance } \\
\text { to output } \\
\text { market }\end{array}$ & 1.48 & 2.81 \\
4 & $\begin{array}{c}\text { Distance to } \\
\text { resources of } \\
\text { information }\end{array}$ & 2.59 & 1.00 \\
\hline
\end{tabular}

Source: primary data (analyzed)

From Table 3, it was shown that the distance of farmers' places to farm/field was approximately 0.6-0.7 $\mathrm{km}$. The respondents places to input markets took the distances 1.5-1.6 km. Distanceof 


\section{Jurnal Ekonomi Pembangunan, 17 (1), Juni 2016, 15-27}

farmers'places to market output were from 1.48 to $2.81 \mathrm{~km}$. Distance of farmers'places to resources were from 1.00 to $2.59 \mathrm{~km}$. Accessibility of this research location was very supportive where as the farms/fields, both input and output market as well as resources information were close to the farmers' places. Not only the farmers of wetland paddy as a leading commodity but also the farmers of wetland paddy as non-leading commodity were easy to acquire farming inputs such as seeds, fertilizers and pesticides, as well as in selling their crops due to their places were close to both input and output markets. The extension agents became the representative of the information resource which were be part of monthly meeting of the farmers' group. This made the distance between the farmers and information resources was not a kind of obstacle.

Performance of infrastructure includes the availability of labeled seeds, organic fertilizers, inorganic fertilizers, pesticides, agricultural tools and machinery, marketing of products and frequency of extension activities. The availability of organic fertilizers, inorganic fertilizers, pesticides, agricultural tools and machinery and the availability of sufficient product marketing available in the field (Appendix 2). Extension activitiesare often done by the extension of the Institute of Agricultural Extension, so it helps farmers to overcome the problems in the field. Availability of infrastructure in the field is very supportive with the farmers farming to reach the optimal production. The performanceof infrastructure research is presented in Appendix 2.

\subsection{Analysis of Wetland Paddy Farming}

Wetland paddy farming was a farming system that analyzed the first growing season (MT-I) or the rainy season in 2014/2015 on a half technical irrigated land. The seeds used by farmers was the seed of new varieties (VUB), as Mekongga, Situbagendit, IR-64, Ciherang and Inpari-23. Average use of seeds as $33 \mathrm{~kg} / \mathrm{ha}$ on wetland paddy farmers as a leading commodity according to agro ecological zones, while the wetland paddy farmers as non-commodity as 37 $\mathrm{kg} / \mathrm{ha}$. Sahara, Alam, and Idris (2007), the results of research in Uepai District, Konawe, that the use of seed in paddy farming was between 30-80 $\mathrm{kg} / \mathrm{ha}$. According to Andriati and Sudana (2007), in Karawang, West Java Province the use of seed is up to $25 \mathrm{~kg} / \mathrm{ha}$.

Fertilization that was done by farmers did not yet follow the fertilizer recommendations which drawn up by the Ministry of Agriculture. For the wetland paddy farmers as a leading commodity according to agro ecological zones, the average use of urea $116 \mathrm{~kg} / \mathrm{ha}$, ZA $33 \mathrm{~kg} /$ ha, SP-36 $50 \mathrm{~kg} / \mathrm{ha}$, KCL $3 \mathrm{~kg} / \mathrm{ha}$, NPK $274 \mathrm{~kg} /$ ha and organic fertilizers 1.24 tonnes/ha, while for the wetland paddy farmers as a non-leading commodity, the use of urea $182 \mathrm{~kg} / \mathrm{ha}$, ZA $82 \mathrm{~kg} /$ ha, SP-36 $25 \mathrm{~kg} / \mathrm{ha}$, KCL $7 \mathrm{~kg} / \mathrm{ha}$, NPK $188 \mathrm{~kg} /$ ha and organic fertilizer 1.43 ton/ha. According to Andriati and Sudana (2007), the results of research in Karawang, West Java Province, the use of urea fertilizer are between $217-263 \mathrm{~kg} /$ ha, SP-36 88-121 kg/ha and KCL 15-26 kg/ha. Sahara et al. (2007), the result of research in Uepai District, Konawe the use of urea fertilizer are $150-250 \mathrm{~kg} / \mathrm{ha}, \quad$ SP-36 $50-150 \mathrm{~kg} / \mathrm{ha}$ and KCL $0-50 \mathrm{~kg} / \mathrm{ha}$. Based on the regulation of the Minister of Agriculture Number 40/Permentan/ OT.140/4/2007 on the recommendation for N, $\mathrm{P}$, and $\mathrm{K}$ in paddy farming specific locations in Bantul, urea fertilizer $250-300 \mathrm{~kg} / \mathrm{ha}$, SP-36 fertilizer $50-100 \mathrm{~kg} / \mathrm{ha}$ and KCL $50 \mathrm{~kg} / \mathrm{ha}$ without organic matter. Fertilization using organic materials such as straw ( $5 \mathrm{ton} / \mathrm{ha}$ ), then the use of urea fertilizer were $230-280 \mathrm{~kg} / \mathrm{ha}$, SP-36 50-100 $\mathrm{kg} / \mathrm{ha}$ without KCL fertilizer. Fertilization using organic materials such as manure (2 tonnes/ha), the urea fertilizer $225-275 \mathrm{~kg} / \mathrm{ha}$, SP-36 $0-50 \mathrm{~kg} /$ ha and KCL $30 \mathrm{~kg} / \mathrm{ha}$. Sirrapa, Rieuwpassa, and Waas (2007), the use of quality seed and fertilizer plaid a role in increasing grain yield. 


\section{Jurnal Ekonomi Pembangunan, 17 (1), Juni 2016, 15-27}

The cost structure of paddy farming include spraying, weeding, harvesting and post-harvest). the cost of production inputs (seed, fertilizer, The cost structure of paddy farming is presented pesticides) and labor (tilling, planting, fertilizing, in Table 4.

Table 4. Cost Structure Paddy Farming MTI 2014/2015

\begin{tabular}{lcccc}
\hline \multirow{2}{*}{ Brief } & \multicolumn{2}{c}{$\begin{array}{c}\text { Leading Commodity } \\
\text { According }\end{array}$} & \multicolumn{2}{c}{$\begin{array}{c}\text { Non-Leading } \\
\text { Commodity }\end{array}$} \\
\cline { 2 - 5 } & Total & Percent & Total & Percent \\
\hline Cost of production input(Rp) & $2,480,574$ & 25.5 & $2,601,509$ & 25.5 \\
Seed & 334,489 & 3.4 & 351,719 & 3.4 \\
Fertilizer & $1,710,115$ & 17.6 & $1,825,123$ & 17.9 \\
Pesticide/Medicine & 435,970 & 4.5 & 424,667 & 4.2 \\
Cost of Labor (Rp) & $7,254,193$ & 74.5 & $7,613,303$ & 74.5 \\
Tillling & $1,747,685$ & 18.0 & $1,951,204$ & 19.1 \\
Seeding & 366,667 & 3.8 & 375,000 & 3.7 \\
Planting & $1,462,566$ & 15.0 & $1,519,599$ & 14.9 \\
Fertilizing & 353,333 & 3.6 & 411,667 & 4.0 \\
Spraying & 520,000 & 5.3 & 526,667 & 5.2 \\
Weeding & $1,064,524$ & 10.9 & $1,087,407$ & 10.6 \\
Harvesting and post-harvest & $1,739,418$ & 17.9 & $1,741,759$ & 17.0 \\
Total cost of farming(Rp) & $9,734,767$ & 100.00 & $10,214,812$ & 100.00 \\
\hline Source: primary data (analyzed) & & & &
\end{tabular}

From Table 4, the portion of the production cost reached $25.5 \%$, while labor costs reached $74.5 \%$ from the total cost of wetland paddy farming. Ariani, Saryoko, and Muttakin (2009), concerning paddy farming during the rainy season on the Prima Tani location, Banten Province (Serang, Pandeglang and Lebak District), costs of production input reaches $21.2 \%$ to $25 \%$, while labor costs reached for over $60 \%$ of the total cost of paddy farming. Andriati and Sudana (2007), paddy farming during the rainy season in Karawang, West Java province in 2005 claimed that expenses used for production input reach $22 \%-25 \%$ of the total cost of paddy farming. Baharudin et al. (2016), the paddy farming input costs reached $42.2 \%$, while operations and employment cost reached $57.8 \%$. Chang et al. (2016), states that the cost of its inputs to produce paddy were less than $40 \%$.

Cost of production input cover the purchase of seeds, fertilizers and pesticides. Cost of production input on the wetland paddy farmers as a leading commodity according to agro ecological zones (AEZ) Rp. 2,480,574.- lower than the wetland paddy farmers as a non-leading commodity Rp. 2,601,509.-. This is because the average seed and fertilizer used by farmers of wetland paddy as a leading commodity according to agro ecological zones lower than wetland paddy as a non-leading commodity. The largest portion of the production input cost used for the provision of fertilizers reached $69 \%-70 \%$, while the portion for the provision of seeds around $14 \%$ and pesticides about 16\%-18\%. According to Ariani et al. (2009), the largest portion of the production input cost was used for fertilizers.

Labor costincluded costs for land preparation, nursery, planting, fertilizing, spraying, weeding and harvesting and post-harvest. The cost of labor in the wetland paddy farmers as a leading commodity according to agro ecological zones (AEZ) Rp. 7,254,193.-, while the wetland paddy farmers as a non-leading commodity Rp. $7,613,303,-$. The largest portion of the labor 


\section{Jurnal Ekonomi Pembangunan, 17 (1), Juni 2016, 15-27}

cost used for the cultivation of land (24\%-26\%), harvest and post-harvest (23\%-24\%). The largest portion of the labor cost used to harvest (Ariani et al., 2009). Total costs of farming of the wetland paddy farmers as a leading commodity according to agro ecological zones (AEZ) Rp. 9,734,767.lower than the wetland paddy farmers as a nonleading commodity Rp. 10,214,812.- or difference Rp. 480,045.-.

The feasibility of wetland paddy farming is determined from the value of $\mathrm{R} / \mathrm{C}$, where the wetland paddy farming is considered feasible if the value of $\mathrm{R} / \mathrm{C}$ is more than one. Production on wetland paddy farmers as a leading commodity according to agro ecological zones (AEZ) was 5.9 tonnes/ha of unhusked harvest was higher than in wetland paddy farmers as a nonleading commodity 5.7 tonnes/ha (Table 7). The production was still lower than the average of wetland paddy farming production Bantul Regency in 2013, which is 6.4 tonnes/ha (BPS Bantul 2014). The average price of unhusked harvest (GKP) on wetland paddy farmers as a leading commodity according to agro ecological zones (AEZ) Rp. 3,567.-, while in wetland paddy farmers as a non-leading commodity Rp. 3,543.

. That grain prices were still lower than the government purchase price (HPP) which was Rp. 3,700.-. Acceptance of farming in the wetland paddy farmers as a leading commodity according to agro ecological zones (AEZ) Rp. 21,130,908. , while in the wetland paddy farmers as a nonleading commodity Rp. 20,315,562.-. Profits earned from farming on wetland paddy farmers as a leading commodity according to agro ecological zones (AEZ) Rp. 11,396,141.- was greater than the profit to the wetland paddy farmers as a nonleading commodity Rp. 10,100,750.-. Wetland paddy farming feasibility analysis is presented in Table 5.

The results of $\mathrm{R} / \mathrm{C}$ analysis of wetland paddy is more than one, so that the wetland paddy farming is considered feasible. $\mathrm{R} / \mathrm{C}$ farming value in wetland paddy farmers as a leading commodity according to agro ecological zones (AEZ) of 2.17 means that any expenses amount $\mathrm{Rp}$ 1,000.to an input that given, gained acceptance $\mathrm{Rp}$. $2,170 . \mathrm{R} / \mathrm{C}$ farming value in wetland paddy paddy farmers as a non-leading commodity of 1.99 means that any expenses amount $R p$ 1,000.- to an input that given, gained acceptance Rp. 1,990.Ariani et al. (2009), research on paddy farming during the rainy season on the location of Prima Tani Banten (Serang District, Pandeglang and Lebak) acquired R/C from 1.9 to 2.3. Andriati and Sudana (2007), research about paddy farming during the rainy season in Karawang, West Java in 2005 acquired R/C 1.54 to 1.70. Sahara et al. (2007), the result ofresearch in Uepai District, Konawe obtained R/C of 2.28.

Table 5. Paddy Farming Feasibility Analysis MTI 2014/2015

\begin{tabular}{lcc}
\hline \multicolumn{1}{c}{ Brief } & $\begin{array}{c}\text { Leading } \\
\text { Commodity } \\
\text { According to } \\
\text { AEZ }\end{array}$ & $\begin{array}{c}\text { Non-Leading } \\
\text { Commodity }\end{array}$ \\
\hline Total cost of & $9,734,767$ & $10,214,812$ \\
farming (Rp) & 5,924 & 5,734 \\
Production (kg/ha) & 3,567 & 3,543 \\
Price (Rp/kg) & $21,130,908$ & $20,315,562$ \\
Acceptance (Rp) & $11,396,141$ & $10,100,750$ \\
Profit (Rp) & 2.17 & 1.99 \\
R/C & 1.13 & \\
NKB & & \\
\hline
\end{tabular}

Source: primary data (analyzed)

The increase in net profit (NKB) from wetland paddy farming as a leading commodity according to agro ecological zones (AEZ) is 1.13. This means that the profit of farming in wetland paddy farmers as a leading commodity according to agro ecological zones (AEZ) 1.13 higher compared with a profit of wetland paddy farmers as a non-leading commodity.

Analysis of the scale of farming can be determined by the break even point of production and the break even point of price. The break even point is used to determine the level of production 


\section{Jurnal Ekonomi Pembangunan, 17 (1), Juni 2016, 15-27}

and the minimum price that must be achieved so that paddy farming could be profitable. Analysis break even paddy farming is presented in Table 6 .

Table 6. Analysis of Break Even Paddy Farming MTI 2014/2015

\begin{tabular}{lcc}
\hline \multicolumn{1}{c}{ Brief } & $\begin{array}{c}\text { Leading } \\
\text { Commodity } \\
\text { According to } \\
\text { AEZ }\end{array}$ & $\begin{array}{c}\text { Non-Leading } \\
\text { Commodity }\end{array}$ \\
\hline $\begin{array}{l}\text { Total cost of } \\
\text { farming (Rp) }\end{array}$ & $9,734,767$ & $10,214,812$ \\
$\begin{array}{l}\text { Production (kg/ } \\
\text { ha) }\end{array}$ & 5,924 & 5,734 \\
$\begin{array}{l}\text { Price (Rp/kg) } \\
\text { Break even } \\
\text { production (kg/ } \\
\text { ha) }\end{array}$ & 3,567 & 3,543 \\
$\begin{array}{l}\text { Break even } \\
\text { price (Rp/kg) }\end{array}$ & 2,729 & 2,883 \\
\hline
\end{tabular}

Source: primary data (analyzed)

Table 8 shows that the break even point of production and the break even point of price on wetland paddy farmers as a leading commodity according to agro ecological zones (AEZ) Bantul were $2,729 \mathrm{~kg} / \mathrm{ha}$ and Rp. $1,643 / \mathrm{kg}$. This means that farming in wetland paddy farmers as a leading commodity according to agro ecological zones (AEZ) was still profitable if the production was not less than $2,729 \mathrm{~kg} / \mathrm{ha}$ or the selling price was not lower than Rp. 1,643/kg. Break even point of production and the break even point of price on wetland paddy farmers as a non-leading commodity is $2,883 \mathrm{~kg} / \mathrm{ha}$ and Rp. $1,781 / \mathrm{kg}$. This means that farming in wetland paddy farmers as a non-leading commodity still profitable if production is not less than $2,883 \mathrm{~kg} / \mathrm{ha}$ or the selling price is not lower than Rp. 1,781/kg.

The implication of this study is that an increase in harvested area, production and productivity in Bantul to do and focused on 10 districts wetland paddy as a leading commodity to agro ecological zones with an area of 11,666.66 hectares, namely Sanden, Kretek, Pundong, Bambanglipuro, Pandak, Bantul, Jetis,
Banguntapan, Kasihan and Sedayu. From the results of this study showed that wetland paddy production as a leading commodity according to agro ecological zones higher than wetland paddy as a non-leading commodity and total costs wetland paddy production as a leading commodity lower than wetland paddy as a non-leading commodity.

\section{Conclusion}

Wetland paddy farming as a leading commodity according to agro ecological zones in Bantul is feasible and more optimal (R/C 2.17) than the non leading commodity (R/C 1.99). Cost of wetland paddy farming as a leading commodity according to agro ecological zones lower than wetland paddy farming as a nonleading commodity. The profit of wetland paddy farming as a leading commodity according to agro ecological zones was 1.13 higher than wetland paddy farming as a non-leading commodity. Scale of wetland paddy farming as a leading commodity according to agro ecological zones was still be profitable if the production of at least $2,729 \mathrm{~kg} /$ ha or a minimum selling price of Rp. 1,643/kg. Scale of wetland paddy farming as a non-leading commodity was still be profitable if the production of at least $2,883 \mathrm{~kg} / \mathrm{ha}$ or a minimum selling price of Rp. 1,781/kg.

Coaching and counseling about the latest technologies in agriculture needs to be done, especially fertilizer technology. Until now, fertilization is done by farmers do not follow fertilizer recommendations that have been prepared by the Ministry of Agriculture. In the future, the use of chemical fertilizers should be reduced even abandoned, and replaced with an organic fertilizer or manure. Dissemination strategy needs to be improved so that farmers willing to adopt the technology, so as to increase production and productivity.

\section{Acknowledgments}

The author would like to thank especially to the Director General of Indonesian Agency for Agricultural Reserach and Development and Director of the Indonesian Center for Agricultural 


\section{Jurnal Ekonomi Pembangunan, 17 (1), Juni 2016, 15-27}

Technology Assessment and Development which has provided the opportunity to continue studies at IPB Bogor. The author also expressed his gratitude to the Head of Agriculture and Forestry Department Bantul Regency, Indonesian Agency of Agricultural Technology of Yogyakarta, extension and farmer groups that have helped in the conduct of research.

\section{Reference}

Adnyana, M.O. dan Kariyasa, K. 1995. Model Competitive Advantage as a Analysis Tools in Choosing The Leading Agricultural Commodity. Agricultural Informatics. $5(2): 25-258$.

Andriati, Sudana, W. 2007. Performance and Financial Analysis of Paddy Farming (Case Primatani Village, Karawang, West Java). Journal of Agricultural Technology Assessment and Development. 10(2): 106118.

Ariani, M., Saryoko, A., Muttaqin, S. 2009. Increasing Profits Paddy Farming Through PTT Approach in Prima Tani Location Banten Province. Journal of Agricultural Technology Assessment and Development. 12 (3): 172-179.

Baharudin, A.A., Arshad, F.M., Tasrif, M., Ibragimov, A. 2016. Impact of Fuel Prices on Paddy Farmer's Expenditure Allocation in Malaysia. British Journal of Applied Research. 1(1): 0005-0009.

[BPS] Central Bureau of Statistics Bantul. 2014. Bantul In Figures 2014.

Chang, Y.C., Norman, T., Uphoff, Yamaji, E. 2016. A Conceptual Framework for EcoFriendly Paddy Farming in Taiwan, Based on Experimentation with System of Rice Intensification (SRI) Methodology. Paddy and Water Environment. 14(1):169-183.

Hendayana, R. 2003. Application Methods Location Quotient (LQ) In the determination of the National Commodities. Agricultural Informatics. 12: 658-675.
[IAARD] Indonesian Agency for Agricultural Research and Development. 2003. General Guidelines: Implementation of the Program Assessment and Information, Communication and Dissemination BPTP. Agency for Agricultural Research and Development. Ministry of Agriculture. Jakarta.

Isgin, T., Bilgic, A., Forster, D.L., Batte, M.T. 2008. Using Count Data Models to Determine the Factors Affecting Farmer's Quantity Decisions of Precisions Farming Technology Adoption. Computer and Electronic in Agriculture. 62:231-242.

Juanda, B. 2009. Methodology of Economic and Business Research. Second Edition. Bogor. IPB Press.

Koirala, K. H., Mishra, A., Mohanty, S. 2016. Impact of Land Ownership on Productivity and Efficiency of Rice Farmers:The Case of the Philippines. Land Use Policy. 50:371378.

Mulyono, J. 2015. Strategy of Agricultural Sector Development in the Agro Ecological Zone Rural Areas Bantul Regency. Thesis Pascasarjana School of Bogor Agricultural University, Bogor. 2015.

Rahmanto, B. dan Adnyana, M.O. 1997. Potential SUTPA In Upgrading Competitiveness of Food Commodities In Central Java. Papers On National Seminar Dynamics of Rural Economy and Agriculture Sector Competitiveness Improvement in Bogor, 5-6 August 1997.

Rangkuti, F. 2009. Analysis of Farmer's Role in Adoption Communication Network Hand Tractor Innovation in Cianjur Regency, West Java. Agro Economic Journal. 27 (1): 45-60.

Rusastra, I.W., Rachman, B., Friyatno, S. 2004. Competitiveness Analysis and Protection Structure of Commodity Crops. http:// pse.litbang.deptan.go.id/ind/pdffiles/pros- 


\section{Jurnal Ekonomi Pembangunan, 17 (1), Juni 2016, 15-27}

02_2004.pdf?q=tadah. Accessed September 6,2014 .

Sahara D, Alam N, Idris. 2007. Analysis of breakeven and sensitivity Against Financial Feasibility Paddy Farming. Journal of Agricultural Technology Assessment and Development. 10(2): 19-125.

Setiyanto, A. 2013. Approach and Implementation of Regional Development of Agricultural Leading Commodities. Agro Economic Journal. 31(2): 171-195.

Sirappa, M.P., Rieuwpassa, A.J., Waas, E.D. 2007. Study of Giving NPK At Some Rice Varieties in North Seram. Journal of Agricultural Technology Assessment and Development. 10(1): 48-56.

Soedjana, T.D. 2007. Farming Systems Integrated Crop-Livestock Farmers In Response Against Risk Factors. Journal of Agricultural Research. 26(2): 82-87.

Soekartawi. 2002. Analysis of Farming. Jakarta. Indonesia University Press (UI-Press).
Suharyanto, Destialisma and Parwati, I.A. 2005. Factors Affecting Seeding Technology Adoption in the province of Bali. Proceedings of the National Seminar. "Socialization In Effort to Accelerating Technological Innovation of Agriculture and Rural Revitalization in Marginal Land”. NTB, 30 to 31 August 2005. Page 122-128.

Sukmawani, R., Haeruman, M., Sulistyowati, L., Perdana T. 2014. Papaya Developmnet Model As A Competitive Local Leading Commodity. Jurnal Ekonomi Pembangunan. 15(2):128-140.

Syafruddin, Kairupan, D.A.N., State, A., Limbongan, J. 2004. Agricultural System Planning and Decision of Leading Commodities Based Agroecology Zones in Central Sulawesi. Journal of Agricultural Research. 23(2): 61-67. 
Avalaible online at http://journals.ums.ac.id

Jurnal Ekonomi Pembangunan, 17 (1), Juni 2016, 15-27

Appendix

Appendix 1. Farmers Characteristics

\begin{tabular}{|c|c|c|c|c|c|}
\hline \multirow[t]{2}{*}{ No } & \multirow[t]{2}{*}{ Farmers Characteristics } & \multicolumn{2}{|c|}{$\begin{array}{l}\text { Leading Commodity } \\
\text { According to AEZ }\end{array}$} & \multicolumn{2}{|c|}{$\begin{array}{l}\text { Non-Leading } \\
\text { Commodity }\end{array}$} \\
\hline & & Total & Percentage & Total & Percentage \\
\hline \multirow{4}{*}{1} & Age & 15 & 100.00 & 15 & 100.00 \\
\hline & $\leq 35$ year & - & - & 2 & 13.34 \\
\hline & b. $36-55$ year & 10 & 66.67 & 8 & 53.33 \\
\hline & c. $\geq 56$ year & 5 & 33.33 & 5 & 33.33 \\
\hline \multirow{6}{*}{2} & Education & 15 & 100.00 & 15 & 100.00 \\
\hline & a. Pre school (0 year) & 1 & 6.67 & - & - \\
\hline & b. Elementary (1-6 year) & 7 & 46.66 & 6 & 40.00 \\
\hline & c. Junior high school (7-9 year) & 6 & 40.00 & 4 & 26.66 \\
\hline & d. High school (10-12 year) & 1 & 6.67 & 3 & 20.00 \\
\hline & e. College ( $\geq 13$ year) & - & - & 2 & 13.34 \\
\hline \multirow{4}{*}{3} & Farming Experience & 15 & 100.00 & 15 & 100.00 \\
\hline & a. $\leq 5$ year & - & - & - & - \\
\hline & b. 6 - 25 year & 6 & 40.00 & 9 & 60.00 \\
\hline & c. $\geq 26$ year & 9 & 60.00 & 6 & 40.00 \\
\hline \multirow{4}{*}{4} & Number of Dependents & 15 & 100.00 & 15 & 100.00 \\
\hline & a. 1-2 People & 6 & 40.00 & 5 & 33.33 \\
\hline & b. 3-4 People & 8 & 53.33 & 8 & 53.33 \\
\hline & c. $\geq 5$ People & 1 & 6.67 & 2 & 13.34 \\
\hline \multirow{7}{*}{5} & Main Job & 15 & 100.00 & 15 & 100.00 \\
\hline & a. Farmers & 15 & 100.00 & 12 & 80.00 \\
\hline & b. Farm labor & - & - & - & - \\
\hline & c. Non farm labor & - & - & 2 & 13.33 \\
\hline & d. Sales & - & - & - & - \\
\hline & e. Goverment employee & - & - & - & - \\
\hline & f. Etc & - & - & 1 & 6.67 \\
\hline \multirow{7}{*}{6} & Main Income & 15 & 100.00 & 15 & 100.00 \\
\hline & a. Farmers & 15 & 100.00 & 11 & 73.33 \\
\hline & b. Agricultural labor & - & - & - & - \\
\hline & c. Non agricultural labor & - & - & 3 & 20.00 \\
\hline & d. Sales & - & - & - & - \\
\hline & e. Goverment employee & - & - & - & - \\
\hline & f. Etc & - & - & 1 & 6.67 \\
\hline
\end{tabular}

Source: primary data (analyzed) 
Avalaible online at http://journals.ums.ac.id

Jurnal Ekonomi Pembangunan, 17 (1), Juni 2016, 15-27

Appendix 2. Infrastructure Research Area

\begin{tabular}{|c|c|c|c|c|c|}
\hline \multirow[t]{2}{*}{ No } & \multirow[t]{2}{*}{ Brief } & \multicolumn{2}{|c|}{$\begin{array}{c}\text { Leading } \\
\text { Commodity } \\
\text { According to AEZ }\end{array}$} & \multicolumn{2}{|c|}{$\begin{array}{l}\text { Non-Leading } \\
\text { Commodity }\end{array}$} \\
\hline & & Total & Percent & Total & Percent \\
\hline \multirow[t]{4}{*}{1} & Availability of labeled seeds & 15 & 100 & 15 & 100 \\
\hline & a. sufficient & 15 & 100 & 15 & 100 \\
\hline & b. moderate & - & - & - & - \\
\hline & c. less & - & - & - & - \\
\hline \multirow[t]{4}{*}{2} & Availability of organic fertilizers & 15 & 100 & 15 & 100 \\
\hline & a. sufficient & 15 & 100 & 15 & 100 \\
\hline & b. moderate & - & - & - & - \\
\hline & c. less & - & - & - & - \\
\hline \multirow[t]{4}{*}{3} & Availability ofinorganic fertilizers & 15 & 100 & 15 & 100 \\
\hline & a. sufficient & 15 & 100 & 15 & 100 \\
\hline & b. moderate & - & - & - & - \\
\hline & c. less & - & - & - & - \\
\hline \multirow[t]{4}{*}{4} & Availabilityof pesticides & 15 & 100 & 15 & 100 \\
\hline & a. sufficient & 15 & 100 & 15 & 100 \\
\hline & b. moderate & - & - & - & - \\
\hline & c. less & - & - & - & - \\
\hline \multirow[t]{4}{*}{5} & $\begin{array}{l}\text { Availabilityof agricultural tools and } \\
\text { machinery }\end{array}$ & 15 & 100 & 15 & 100 \\
\hline & a. sufficient & 15 & 100 & 15 & 100 \\
\hline & b. moderate & - & - & - & - \\
\hline & c. less & - & - & - & - \\
\hline \multirow[t]{4}{*}{6} & $\begin{array}{l}\text { Availability of sufficient product } \\
\text { marketing }\end{array}$ & 15 & 100 & 15 & 100 \\
\hline & a. sufficient & 15 & 100 & 15 & 100 \\
\hline & b. moderate & - & - & - & - \\
\hline & c. less & - & - & - & - \\
\hline \multirow[t]{4}{*}{7} & Frequency of extension & 15 & 100 & 15 & 100 \\
\hline & frequently & 15 & 100 & 15 & 100 \\
\hline & b. rarely & - & - & - & - \\
\hline & c. never & - & - & - & - \\
\hline
\end{tabular}

Source: primary data (analyzed) 